\title{
PENGARUH KUALITAS PELAYANAN DAN NILAI PELANGGAN TERHADAP KEPUASAN PENGUNJUNG TEMPAT WISATA HAIROS WATERPARK MEDAN
}

\author{
Apriandi Sembiring \\ Alumni Jurusan Manajemen Fakultas Ekonomi Universitas Negeri Medan \\ Sri Rezeki \\ Dosen Jurusan Manajemen Fakultas Ekonomi Universitas Negeri Medan
}

\begin{abstract}
This research aims to determine the effect of Service Quality and Customer Value at the Visitor Satisfaction at Hairos Waterpark Medan. Based on the results of pre-study to do an interview to Manager Hairos Waterpark Medan, the population in this study is that consumers who visit with the average number of 3,468 per month. Accindental sampling using sampling with a sample of 97 people visitors. The test used is the test data quality and classical assumption. The hypothesis test uses multiple linear regression analysis, $f$ test and $t$ test. Validity of test results obtained $t>t$ table for each item reliability test questions and questionnaires obtained a Cronbach alpha of each variable is 0.792 for the variable $X_{1}, 0.698$ for $X_{2}$ and 0.605 for the variable $Y$. This value is greater than the level that is significantly rtabel 0.361 . The data analysis of each variable regression equation $Y=9.618+0.256 X 1+0.216 X 2+e$. Retrieved $R 2$ of 0.234 , which means the $X 1$ and $X 2$ explain the effect on variable $Y$ by $23.4 \%$ while the remaining $76.6 \%$ is explained variables outside the company. The resulting partial test each independent variables affect the dependent variable with research significance less than 0.05 , and the results of the test-simultaneous calculation of 14.369 with Ftable 3.09 which means Fresult $>F$ table with a level of significant $(\alpha) 0,000<0$, 05, which means that the hypothesis is accepted that the quality of service and customer value together significant effect on visitor satisfaction hairos waterpark attractions terrain.
\end{abstract}

Keyword : Service Quality, Customer Value, Visitor Satisfaction

PENDAHULUAN

Medan merupakan salah satu kota terbesar di Indonesia yang memiliki jumlah penduduk yang sangat padat dan dengan heterogenitas yang tinggi. Padatnya rutinitas dan aktivitas masyarakat merubah pola dan gaya hidup yang semakin sibuk dan sempitnya waktu membuat banyak orang merasa lelah sehingga membutuhkan tempat wisata untuk melepaskan ketegangan dan kejenuhan guna memperoleh suasana baru yang menyegarkan dan menghibur. Tempat wisata merupakan salah satu elemen yang penting dalam proses pemenuhan kebutuhan akan rekreasi dan wisata. Meningkatnya kebutuhan akan tempat rekreasi yang terjangkau mendorong pertumbuhan tempat wisata untuk mengembangkan diri melalui suatu atraksi wisata, akomodasi serta aksesibilitas.

Hairos Waterpark Medan adalah salah satu tempat wisata yang 
bisa memenuhi kebutuhan akan rekreasi dan wisata. Hairos Waterpark Medan ini terletak di Jln. Jamin Ginting $\mathrm{Km}$ 14,5 Medan. Hairos Waterpark Medan ini merupakan salah satu lokasi rekreasi air terbesar di kota Medan. Maka dari itu banyak masyarakat kota Medan atau bahkan dari luar kota yang datang untuk berekreasi baik dengan keluarga ataupun dengan teman. Kebanyakan orang berkunjung yaitu pada saat hari libur atau pada akhir pekan. Pengunjung yang datang ke Hairos Waterpark Medan dapat menikmati produk permainan-permainan yang ada yaitu seperti bom bom car, happy dragon, mini flight, kuda pusing, video game, yang dilengkapi dengan café untuk bersantai. Ada juga kebun binatang, perahu sampan, motor ATV dan kincir angin.

Dalam upaya mewujudkan kepuasan konsumen Hairos Waterpark telah menerapkan berbagai strategi, yaitu dengan mengutamakan kualitas pelayanan dan kesigapan petugas dalam melayani pengunjung. Selain itu pihak Hairos Waterpark juga telah menjaga kualitas dari produknya dengan merawat dan memperbaharui wahana-wahana yang mereka sediakan, dan juga melakukan berbagai usaha promosi untuk meningkatkan jumlah pengunjung.

Pihak Hairos Waterpark Medan harus lebih memperhatikan faktor - faktor yang mempengaruhi kepuasan dan minat kunjungan wisatawan, terutama dari sisi kualitas pelayanan dan nilai pelanggan. Agar dapat bersaing dengan pesaingnya dan dapat meningkatkan jumlah pengunjung, karena kenaikan dan penurunan jumlah wisatawan yang terlalu drastis tidaklah baik bagi kelangsungan hidup perusahaan.

\section{KAJIAN PUSTAKA}

Kepuasan Konsumen

Tjiptono

(2010:24)

menyatakan bahwa kepuasan pelanggan merupakan evaluasi purna beli dimana alternatif yang dipilih sekurang-kurangnya sama atau melampaui harapan pelanggan, sedangkan ketidakpuasan timbul apabila hasil (outcome) tidak memenuhi harapan. Perbandingan antara harapan dan kinerja yang didapatkan oleh konsumen akan menghasilkan perasaan senang atau tidak senang. Apabila kinerja sesuai atau bahkan melebihi dari yang diharapkan, maka konsumen akan merasa senang atau puas. Sebaliknya apabila kinerja berada di kurang dari yang diharapkan, maka pelanggan akan merasa kecewa atau tidak puas.

Kepuasan pelanggan juga dapat didefinisikan sebagai tingkat perasaan seseorang setelah membandingkan kinerja dari sebuah produk yang dirasakan dengan yang diharapkan. Dengan memiliki tingkat kepuasan yang tinggi, dapat meningkatkan meningkatkan loyalitas pelanggan dan mencegah perputaran pelanggan, mengurangi sensivisitas harga, mengurangi biaya kegagalan pemasaran, dan mengurangi biaya operasi (Rangkuti 2013:23).

Menurut Kotler (dalam Tjiptono 2010:121) kepuasan konsumen dapat didefenisikan sebagai suatu keadaan dimana kebutuhan, keinginan, dan harapan konsumen dapat terpenuhi melalui produk yang dikonsumsi. 
Secara umum kepuasan konsumen dapat dikatakan sebagai perasaan senang atau kecewa seseorang dari perbandingan antara produk yang dibeli sesuai atau tidak dengan harapannya. Sedangkan menurut Irawan (2013:31) menyatakan "kepuasan didefenisikan sebagai evaluasi setelah pembelian hasil dari perbandingan antara harapan sebelum pembelian dengan kinerja sesungguhnya".Kepuasan pelanggan akan dipengaruhi oleh sistem pengiriman produk, performa produk atau jasa, citra perusahaan, citra produk /merek, nilai harga yang dihubungkan dengan nilai yang diterima pelanggan, prestasi karyawan, keunggulan dan kelemahan pesaing.

Memuaskan kebutuhan konsumen sebagai konsumen adalah keinginan setiap perusahaan. Selain faktor penting bagi kelangsungan hidup perusahaan, memuaskan kebutuhan konsumen dapat meningkatkan keunggulan dalam persaingan. Konsumen dapat meningkatkan keunggulan dalam persaingan. Konsumen yang puas terhadap produk dan jasa pelayanan cenderung untuk membeli kembali produk dan menggunakan kembali jasa pada saat kebutuhan yang muncul kembali dikemudian hari. Hal ini berarti merupakan factor kunci bagi konsumen dalam melakukan pembelian ulang yang merupakan porsi terbesar dari volume penjualan perusahaan.

\section{Kualitas Pelayanan}

Menurut Parasuraman (2008), kualitas pelayanandapat didefinisikan sebagai seberapa jauh perbedaan antara kenyataan dan harapan pelanggan atas layanan yang mereka terima atau peroleh. Sedangkan Tjiptono (2007:120) menyatakan bahwa kualitas pelayanan adalah tingkat keunggulan yang diharapkan konsumen dan pengendalian atas tingkat keunggulan tersebut untuk memenuhi keinginan konsumen.

Berikut ini merupakan pendapat beberapa ahli mengenai pengertian kualitas pelayanan yaitu:

a. Menurut Lewis and Booms (dalam Tjiptono, 2007:121) menyatakan "kualitas pelayanan dapat diartikan sebagai ukuran seberapa bagus tingkat layanan yang diberikan mampu sesuai dengan ekspetasi pelanggan".

b. Menurut Lovelock (dalam Utami, 2010:291) menyatakan "kualitas pelayanan adalah perspektif konsumen dalam jangka panjang dan merupakan evaluasi kognitif dari transfer jasa"

Selanjutnya dijelaskan oleh Kotler (dalam Tjiptono, 2014:124) menyatakan "apabila jasa yang diterima atau dirasakan sesuai dengan yang diharapkan, maka kualitas jasa atau pelayanan dipersepsikan baik dan memuasakan. Jika jasa atau pelayanan diterima rendah dari pada yang diharapkan maka kualitas yang dipersepsikan buruk".

\section{Nilai Pelanggan}

Menurut Sweeney \& Soutar (2001:204) nilai pelanggan merupakan keseluruhan penilaian pelanggan tentang kegunaan suatu produk yang berdasar pada persepsi tentang apa yang diterima dan apa 
yang diberikan. Sedangkan menurut Rangkuti (2013:31) nilai pelanggan sebagai pengkajian secara menyeluruh manfaat dari suatu produk, didasarkan persepsi pelanggan atas apa yang didapat dengan biaya yang dikeluarkan.

Anderson dkk, (dalam Tjiptono, 2007:296) menyatakan bahwa nilai pelanggan merupakan perceived worth dalam unit moneter atas serangkaian manfaat ekonomis, teknis, layanan dan social sebagai pertukaran atas harga yang dibayarkan untuk suatu produk. Di sisi lain Monroe (dalam Tjiptono, 2007:296) mengemukakan bahwa nilai pelanggan adalah tradeoff antara persepsi pelanggan terhadap kualitas atau manfaat produk dan pengorbanan yang dilakukan lewat harga yang dibayarkan.

Nilai pelanggan merupakan peningkatan hasil harga dalam peningkatan pengorbanan moneter bagi pelanggan, sehingga berdampak negatif pada nilai kepada pelanggan (Teas, et al. 2000). Persepsi pembeli tentang nilai menggambarkan sebuah perbandingan antara kualitas atas keuntungan yang mereka rasakan dari produk tersebut dengan pengorbanan yang mereka rasakan ketika membayar harga produk.

Hal serupa juga dikatakan oleh Plewa, et al. (2006), bahwa nilai pelanggan merupakan kualitas yang dirasakan konsumen yang disesuaikan dengan harga relatif dari produk yang dihasilkan oleh suatu perusahaan.
Dengan nilai pelanggan kita dapat mengartikan ikatan emosional yang terbentuk antara konsumen dengan produsen menggunakan suatu produk atau jasa penting yang diproduksi oleh produsen dan menemukan produk tersebut memberikan suatu tambahan nilai. Hal ini diindikasikan bahwa hubungan emosional yang tercipta antara konsumen dengan produsen dapat menciptakan timbal balik yang berdampak positif bagi keduanya.

\section{METODE PENELITIAN}

Penelitian ini dilakukan di Tempat Wisata Hairos Waterpark Medan yang berlokasi di Jln. Jamin Ginting Km 14,5, Medan Sumatera Utara. Sampel yang diambil dalam penelitian adalah konsumen yang melakukan pembelian sebesar 97 orang responden. Metode penelitian sampel menggunakan metode Accidental Sampling.

Teknik analisis data yang digunakan dalam penelitian ini adalah analisis regresi linear berganda. Untuk menguji kebenaran hipotesis pertama digunakan uji $\mathrm{F}$ yaitu untuk menguji keberartian/signifikansi regresi secara keseluruhan

\section{HASIL PENELITIAN DAN PEMBAHASAN}

Hasil Peneltian

Analisis Regresi Linier Berganda

Dari data hasil SPSS di atas dapat dijelaskan sebagai berikut : $\hat{\mathbf{Y}}=\mathbf{9 , 6 1 8}+\mathbf{0 , 2 5 6} \mathbf{X} 1+\mathbf{0 , 2 1 6} \mathrm{X} 2+\mathrm{e}$

1. Konstanta sebesar 9,618 menyatakan bahwa jika tidak ada variabel variabel $X$ (Kualitas Pelayanan dan Nilai Pelanggan) 
maka kepuasan pengunjung akan tetap sebesar 9,618, dengan asumsi faktor lain konstan.

2. Koefisien regresi X1 sebesar 0,256 menunjukkan bahwa jika terjadi peningkatan satu satuan kualitas pelayanan maka kepuasan pengunjung akan meningkat sebesar 0,256 dengan asumsi variabel lain konstan.

3. Koefisien regresi X2 sebesar 0,216 menunjukkan bahwa jika nilai pelanggan ditingkatkan sebanyak satu satuan, maka Kepuasan Pengunjung akan meningkat sebesar 0,216 dengan asumsi variabel lain konstan.

\section{Uji Hipotesis}

Pengujian hipotesis penelitian dilakukan untuk menguji ketiga hipotesis penelitian yang telah dipaparkan sebelumnya.Untuk mengetahui apakah variabel independen dalam model regresi berpengaruh terhadap variabel dependen, maka dilakukan pengujian dengan menggunakan uji $t$ ( $t$ test) dan uji $\mathrm{F}$ (F test).

Uji statistik $t$ dilakukan untuk menguji pengaruh dari variabel independen terhadap variabel dependennya secara individu. Hal ini dapat dilihat dari nilai signifikan $\mathrm{t}$ yang dihasilkan dari perhitungan. Apabila nilai signifikan $t<$ tingkat signifikan (0.05) maka variabel independen secara individu berpengaruh terhadap variabel dependennya, sebaliknya jika nilai signifikan $\mathrm{t}>$ tingkat signifikansi (0.05) maka variabel independennya secara individu tidak berpengaruh terhadap variabel dependennya.

\section{Uji Parsial (Uji t)}

Dari hasil SPSS didapat hasil analisis uji $\mathrm{t}$ untuk masing-masing variabel independen adalah sebagai berikut :

1. Nilai t hitung variabel Kualitas Pelayanan 3,659>dari $t_{\text {tabel }}$ yaitu 1,661 dan nilai signifikan $0.002<$ 0,05 Hal ini berarti hipotesis diterima yaitu : Kualitas Pelayanan secara parsial berpengaruh positif dan signifikan terhadap Kepuasan Pengunjung Tempat Wisata Hairos Waterpark Medan.

2. Nilai $t$ hitung variabel Nilai Pelanggan 2,690> dari $t$ tabel yaitu 1.661 dan nilai signifikan $0.004<$ 0,05. Hal ini berarti hipotesis diterima yaitu :Nilai Pelanggan secara parsial berpengaruh positif dan signifikan terhadap Kepuasan Pengunjung Tempat Wisata Hairos Waterpark Medan.

\section{Uji Serentak (Uji F)}

Pengaruh dari kedua variabel bebas secara serentak terhadap variabel terikat dapat dilihat dari hasil uji $\mathrm{F}$. adapun syarat dari uji $\mathrm{F}$ adalah jika Fhitung $>$ Ftabel maka Ho ditolak dan $\mathrm{H} 1$ diterima.

Dari hasil SPSS diperoleh bahwa nilai $F=14,369$ dengan tingkat signifikansi $0,000<0,05$. F tabel dapat dilihat pada table statistik (Terlampir) pada tingkat signifikansi 0,05 dengan df 1 (Jumlah variabel-1) $=2$, dan df $2(\mathrm{n}-\mathrm{k}-1)$ atau $97-2-1$ $=94$ Setelah mengetahui $\mathrm{F}$ hitung, maka akan di bandingkan dengan $\mathrm{F}$ table dengan taraf kesalahan $5 \%$ adalah $=3,09$ maka $F$ hitung $=14,369$ $>\mathrm{F}$ table ( 3,09). Dengan demikian, dapat ditarik kesimpulan koefisien arah regresi berganda pada taraf 
signifikan 0.05 yang artinya Kualitas Pelayanan dan Nilai Pelanggan secara bersama-sama berpengaruh positif dan signifikan terhadap Kepuasan Pengunjung tempat wisata Hairos Waterpark.

Untuk mengetahui seberapa besar Persentase Pengaruh variabel bebas terhadap variabel terikat atau untuk melihat seberapa besar variabel bebas dapat menjelaskan pengaruhnya terhadap variabel terikat.

\section{Uji Koefisien Determinasi $\left(\mathbf{R}^{2}\right)$}

Dari hasil SPSS dapat dilihat bahwa koefisien determinan $\left(\mathrm{r}^{2}\right)$ adalah sebesar 0,234. Nilai ini menunjukan bahwa variabel Kepuasan Pengunjung (Y) dipengaruhi oleh variabel Kualitas Pelayanan $\left(\mathrm{x}_{1}\right)$ Dan Nilai Pelanggan $\left(\mathrm{x}_{2}\right)$ secara bersama-sama sebesar $23,4 \%$ dan sisanya $76,6 \%$ dipengaruhi oleh Variabel lain yang tidak dibahas dalam penelitian ini.

Berdasarkan hasil penelitian bahwa nilai $\mathrm{R}^{2}$ sebesar 0,234 yang berarti variabel Kualitas Pelayanan dan Nilai Pelanggan memberikan pengaruh terhadap Variabel Kepuasan Pengunjung sebesar 23,4\%, Sedangkan sisanya $76,6 \%$ dijelaskan oleh faktor lain diluar dari Variabel penelitian ini.

\section{Pembahasan Hasil Penelitian}

Jika ditinjau dari pengaruh secara parsial (Uji t), variabel Kualitas Pelayanan berpengaruh secara positif dan signifikan terhadap Kepuasan Pengunjung Tempat Wisata Hairos Waterpark Medan, hal ini terlihat dari nilai signifikan 3.659>dari $\mathrm{t}$ tabel yaitu 1,661 dan nilai signifikan $0.002<0,05$.
Variabel Nilai Pelanggan secara parsial berpengaruh secara positif dan signifikan terhadap Kepuasan Pengunjung Tempat Wisata Hairos Waterpark Medan, hal ini terlihat dari nilai signifikan Nilai Pelanggan $2,690>$ dari $t$ tabel yaitu 1.661 dan nilai signifikan $0.002<0,05$.

Dari hasil penelitian juga membuktikan Hipotesis diterima dengan adanya hasil secara simultan (uji $\mathrm{F}$ ) yaitu $\mathrm{F}$ hitung $=14,369>\mathrm{F}$ tabel ( 3,09), dengan demikian dapat ditarik kesimpulan koefisien arah regresi berganda pada taraf signifikan 0,05 yang artinya Kualitas Pelayanan dan Nilai Pelanggan berpengaruh positif dan signifikan terhadap Kepuasan Pengunjung Tempat Wisata Hairos Waterpark.

\section{PENUTUP}

Berdasarkan analisis data dan evaluasi Pengaruh Kualitas Pelayanan dan Nilai Pelanggan Terhadap Kepuasan Pengunjung maka penulis menarik kesimpulan:

1. Berdasarkan Uji $F$ dapat disimpulkan bahwa secara simultan variabel bebas Kualitas Pelayanan dan Nilai Pelanggan berpengaruh positif dan signifikan terhadap Keputusan Pembelian.

2. Variabel Kualitas Pelayanan disimpulkan bahwa variabel Kualitas Pelayanan berpengaruh positif dan signifikan secara parsial terhadap Kepuasan Pengunjung.

3. Variabel Nilai Pelanggan disimpulkan bahwa variabel Nilai Pelanggan berpengaruh positif dan signifikan secara parsial terhadap Kepuasan Pengunjung. 
4. Untuk uji koefisien determinasi $\mathrm{R}$ Square diperoleh nilai sebesar 0,234 . Nilai $R$ Square menunjukkan bahwa variabel independen yaitu variabel kualitas pelayanan dan nilai pelanggan mampu menjelaskan variabel dependen yaitu Kepuasan pengunjung sebesar $0,234(23,4 \%)$ dan sisanya sebesar $76,6 \%$ dipengaruhi oleh faktorfaktor lain yang tidak dibahas dalam penelitian ini.

DAFTAR PUSTAKA

Ariani, Wahyu. 2007. Manajemen Kualitas. $\quad$ Yogyakarta: Andi.

Aryani, Dwi dan Febrina Rosinta. 2010. "Pengaruh kualitas pelayanan terhadap kepuasan pelanggan dalam membentuk loyalitas pelanggan". Jurnal ilmu administrasi dan orgnisasi. Vol.17 Hal.114-126. Universitas Indonesia.

Arikunto, Suharsimi. 2006. Prosedur Penelitian Suatu Pendekatan Praktek (Edisi Revisi V). Jakarta: PT Rineka Cipta.

Azwar, Saifudin. 2009. Metode Penelitian. Yogyakarta: Pustaka Pelajar.

Detmuliati, Alditia dkk. "Pengaruh kualitas pelayanan terhadap kepuasan pengunjung di objek wisata Riau Fantasi Libersa Water \& Themepark". Jom FISIP. Vol.2 No.1. Universitas Riau.

Farida, Siti Ning. 2014. "Pengaruh kualitas layanan dan nilai pelanggan terhadap kepuasan pelanggan speedy di Surabaya”. Jurnal Ekonomi Pembangunan. Vol.5 No.1. UPNV Jawa Timur.

Ferdinand, Agusty. 2006. Structural Equation Modelling dalam Penelitian Manajemen, Edisi Empat. Semarang: Badan Penerbit Universitas Diponegoro.

Ikasari, Ajeng Utami dkk. 2013. "Pengaruh nilai pelanggan dan kualitas pelayanan terhadap kepuasan pelanggan (Studi kasus pada penumpang KA Kaligung Mas di stasiun Poncol Semarang)". Diponegoro Journal Social and Politic. Vol.1 No.2 Hal.1-8. Universitas Diponegoro.

Irawan, Handi. 2013.Prinsip Kepuasan Pelanggan. Jakarta: PT. Elex Media Komputindo Kelompok Gramedia.

Kasmir. 2008. Etika Customer Service. Jakarta: Raja Grafindo Persada.

Kotler, Philip dan Gary Armstrong. 2008. Prinsip-prinsip

Pemasaran. Jakarta: Salemba Empat. . 2007. Manajemen Pemasaran Edisi Millenium. Jakarta : Indeks.

Lupiyoadi, Rambat. 2011. Manajemen Pemasaran Jasa: Teori dan Praktik. Jakarta: Salemba Empat.

Parasuraman, A. dkk. 2008 "A Multiple-Item Scale for Measuring Consumer Perception of Service 
JURNAL PLANS

Penelitian Ilmu Manajemen \& Bisnis

ISSN: $1978-7057$

E-ISSN: 2527-306X

Quality”. Journal of Retailing, Vol. 64. pp 1240

Plewa, C. dan Quester, Q. 2006. "The Impact of Commitment, Trust and Champinship". International Journal of Technology Transfer and Commercialitation. Vol. 5 No. 1 Hal. 79-101.

Rahman, Diandaris Nurhandika. 2013. "Pengaruh Kualitas Pelayanan, Fasilitas, Persepsi Harga dan Lokasi Terhadap Kepuasan Konsumen Pada Pemancingan Ngembel Asri unung Pati Semarang. Skripsi. Semarang: Fakultas Ekonomi Universitas Negeri Semarang

Rangkuti, Freddy. 2013. Measuring Customer Satisfsction. Jakarta: PT Gramedia Pustaka Utama.

Riduwan \& Akdon. 2007. Rumus dan Data dalam Analisis Statistik untuk Penelitian (Administrasi PendidikanBisnis-PemerintahanSosial-KebijakanEkonomiHukumManajemen-Kesehatan). Bandung: Alfabeta.

Shoki,Mohd Bin Md.Ariff. 2012. Relationship Between Customers' Perceived Values, Satisfaction and Loyalty of Mobile Phone Users. Rev. Integr. Bus. Econ. Res. Vol 1(1)

Siwantara, I Wayan. 2011. "Pengaruh nilai pelanggan terhadap kepuasan loyalitas pelanggan serta kinerja customer relationship management (Studi pada halo corporate $\mathrm{Pt}$ Telkomsel Bali”. Jurnal Bisnis dan kewirausahaan. Vol.7 No.3 Tahun 2011. Politeknik Negeri Bali.

Stevianus. 2014. "Pengaruh atraksi wisata, fasilitas, dan kualitas pelayanan terhadap kepuasan pengunjung di taman margasatwa ragunan Jakarta". Jurnal Ekonomi Bisnis. Vol.19 No.3 Tahun $2014 . \quad$ Universitas Gunadarma

Sugiyono . 2010.Metode Kuantitatif dan Kualitatif $R \& D$. Bandung: CV. Alfa Beta. . 2008. Metode Penelitian Bisnis. Bandung: Alfabetha.

Swastha, Basu. 2010. Azas - Azas Marketing. Yogyakarta: Liberty.

Sweeney, J.C. dan Soutar, G,N. (2001). Consumer Perceived Value: The Development of A Multiple Item Scale. Journal of Retailing. 77: 203-220

Teas, R. dan Agarwal, S. 2000. The Effects of Extrinsic Product Cues on Consumer Perceptions of Quality, Sacrifice and Value. Journal of The Academy of Marketing Science. Vol. 28 No. 2 Hal. 78-90.

Tjiptono, Fandi. 2014. Service, Quality \& Satisfaction. Yogyakarta: Andi 2011. Service Manajement Mwujudkan Layanan Prima, 
JURNAL PLANS

Penelitian Ilmu Manajemen \& Bisnis

ISSN: 1978-7057

E-ISSN: 2527-306X

EdisiPertama. Yogyakarta: Andi.

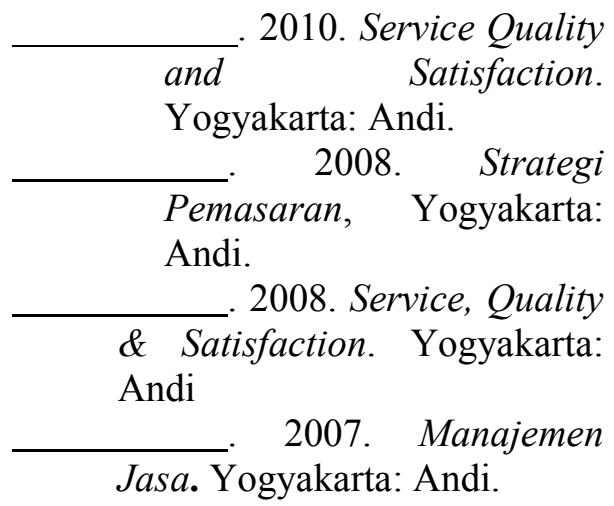

- 2006. Prinsip Prinsip Total Quality Service (TQS). Yogyakarta: Andi. 2006. Strategi Pemasaran. Yogyakarta: Andi

Umar, Husein. 2008. Riset Strategi Pemasaran. Jakarta: Pt. Gramedia Pustaka Utama.

Utami, Christina Whidya. 2010. Manajemen Ritel. Edisi 2. Jakarta: Salemba Empat 